\title{
Does Aid for Trade Enhance Exports by Kenya in COMESA
}

\author{
Paul Otung (PhD Economics) \\ UK Department for International Development Kenya, P.O Box 30465-00100. Nairobi, Kenya
}

\begin{abstract}
There is limited empirical evidence that establish a link between aid for trade and trade outcomes between the countries receiving aid. This study examine whether aid for economic infrastructure, and policy and regulatory reforms affect trade by Kenya to COMESA countries. Using an augmented gravity model, the study find both aid categories to increase exports. Aid for economic infrastructure is economically significant even when aid for policy is absent. While aid for economic infrastructure positively complement aid for policy and regulations. The policy implication is that donors should provide both categories of aid to promote regional trade.
\end{abstract}

Keywords: Aid for Trade, Trade Facilitation, Infrastructure, Policy and Regulations, International Trade, Common Market of Eastern and Southern Africa (COMESA),

DOI: $10.7176 / \mathrm{JESD} / 11-12-11$

Publication date:June 30th 2020

\section{Introduction}

International trade is identified as one way to expand economic development and thus reduce poverty (Vigil 2012). Indeed, global trade has steadily increased over time, such that in the last five decades beginning 1950 up to 2004, on average, world trade expanded by 5.9 per cent and 7.2 per cent per annum for manufactured commodities (Hummels, 2007). The expansion in world trade comes after successive multilateral trade negotiations under General Agreement on Tariffs and Trade (GATTS) and its successor the World Trade Organisation (WTO). The outcome from these multilateral trade negotiations have been broad trade liberalisation and binding commitments by countries to minimise measures that distorts trade like high tariff policies and product subsidies. There has been a gradual decline in applied tariffs and general reduction in international transactions costs across the world.

The global picture however, disguises the mixed trade performance in many countries and regions. There is concern that non-tariff factors continue to limit international trade (Busse et al., 2011). Due to regional differences and disparities in income levels, some countries are yet to fully integrate into the global supply chains. These include thirty-one landlocked developing countries around the world, whose transaction costs remain high compared to coastal countries (Kharel and Belbase, 2010; Chowdhury and Erdenebileg, 2006).

Sub-Saharan Africa (SSA) is one such region yet to achieved progress in global trade. This is evident from its marginal share of world merchandize trade (exports and imports), that was about 2.8 per cent of total world exports and 2.5 per cent of imports between 2000 and 2010 (UNECA, 2013). Besides the export basket from the continent are largely composed of primary commodities and minerals. Manufactured goods constitute only 30 per cent of SSA export trade (Iwanow and Kikpatrick 2007, UNECA 2013).

The marginalisation of SSA in international trade is a puzzle owing to the abundance of natural resource and surplus labour. There is varied explanations why the continent is unable to exploit her comparative advantages in international trade. Some advanced poorly executed trade liberalisation policies and weak institutional framework (Iwanow and Kikpatrick, 2007; Turkson 2012). While others point at poor capital endowments which limit investments in modern transport and trade related infrastructure (Turkson, 2012). Others relate poor trade performance to hostile geographical features occasioned by long distances and landlocked territories (Sachs et al., 2004).

SSA is perceived as a high cost destination with limited opportunities for trade (Iwanow and Kirkpatrick, 2007; Collier and Gunning, 1997). High transactions costs are identified to be particularly severe among the landlocked countries where 60 per cent of trading costs is related to poor transport infrastructure compared to 40 per cent in coastal countries (Limao and Venables, 2001). There are cross-border trade barriers including cumbersome border procedures, transit delays and absence of clear certification mechanisms (Vigil 2012). Aid to mitigate these constraints is meant to generate huge returns (ibid).

Overseas development assistance (ODA) was redesigned to include funds for trade facilitation above regular development assistance to assist countries with limited financial resource and capacity. The necessary reforms were deemed costly for developing countries (Harllert 2012).

There is limited evidence how aid for trade and affect trade outcomes, Aid policy makers say aid stimulate trade (Llyod et al., 2010), giving reference to the different channels used to deliver aid for trade. In addressing supply side constraints, aid proponents assert that it improves the productive capacity of countries, reduce transactions costs and allow firms to diversify (ODI, 2013, Busse et al., 2011). Aid for trade therefore serve as complementary to domestic savings, investment and economic growth through induced public expenditure (Vijil and Wagner, 2010, Suwa-Eisenman and Verdier, 2007; Adam and Bavan, 2006). However, there is limited 
empirical work examining whether aid for trade increase trade among the countries receiving such aid.

\section{Aid for Trade and Trade Facilitation}

Aid for Trade is defined as funds to developing countries intended to expand exports, increase market access and integrate these countries into world trade (WTO 2005). This include four categories of funds for: trade policy and regulations, economic infrastructure, boosting productive capacity, and trade related adjustment. The categories define the instruments and form of delivering aid for trade. WTO noted that the definition was inclusive of the main challenges which increase the costs of trade in poor countries (OECD/WTO, 2011).

An alternative meaning used by the World Bank (2006), define aid for trade based on the programmes, funded like macro-economic adjustments, solving supply side constraints and adjustments resulting from trade preference erosion. While OECD focus on factors which limit trade including poor infrastructure and transport networks, logistics performance, conformity to international product standards, enhancing capacity in border procedures and building productive capacity of countries (Hoekman and Shepard, 2013; Hoekman and Njinkeu, 2007; Hoekman and Wilson, 2010).

\subsection{Trade Facilitation}

Trade facilitation is a major trade policy agenda for SSA countries. SSA countries include trade facilitation programmes as part of their RTA objectives. This is being achieved through funds to improve infrastructure, policy and regulations, and increasing domestic productive capacity, including reducing the effects of trade barriers (Lemi, 2014). COMESA region suffers the constraints imposed by poor trade facilitation like poor regional coordination. For example, the cost per day within COMESA-SADC-EAC region, is estimated to be between US dollar 200 and US dollar 400 when trucks are stationary awaiting border clearance (Pearson 2011). The market failures manifested in port inefficiencies and inadequate infrastructure $(\mathrm{EABC}, 2011)$. Therefore, the formation of the EACCOMESA-SADC Tripartite and inclusion of the Comprehensive Tripartite Trade and Transport Facilitation Programme (CTTTFP) and more recent the Africa Continental Free Trade Area is meant to lower trade costs and increase trade integration among the countries.

Kenya is among the top aid for trade recipients in SSA (OECD/WTO, 2013). ODA disbursement has been increasing with a drop in in 2013, economic infrastructure gets more funding relative to policy and regulatory reforms. Although there is limited evidence that greater investment in infrastructure without complementary policy reforms is effective in facilitating trade World Bank (2010). Hoekman and Ninkeu (2011) explained that the effect of policy induced delays is not usually limited to a single country.

Despite implementing trade facilitation measures like one-stop-border posts, 24-hour border operations, electronic customs clearance, harmonising technical standards and investment in the Northern transport corridor (International Trade Centre, 2012). Kenya was ranked at 75 globally in trade facilitation (World Bank, 2014).

\section{Research Problem}

In Kenya there are operational inefficiencies at the port in Mombasa, inadequate infrastructure along the major transport corridors, weak institutions and coordination failures. These are key determinants of the country's low global ranking in the ease of doing business and trade. There is evidence that non-tariff measures increase the cost of trade in the country. Poor trade facilitation is persistent, notwithstanding the value of aid for trade and regional commitments to eliminate non-tariff barriers according to Article 13 of EAC Customs Union protocol, signatory to the EAC-COMESA-SADC Tripartite agreement and ratifying the recent Africa Continental Free Trade Area. But is not fully understood the extent by which aid for trade educes trade barriers and consequently increase exports in Kenya. Such limited knowledge constraints the policy choices for effective trade facilitation and progress into deeper regional integration. This paper partially fills this empirical gap on the effect of aid for trade facilitation.

\subsection{Research Questions}

The main research question is: how effective is aid for trade in promoting trade flows? This research intends to answer the following specific questions: to what extent does aid for trade improve Kenya's A export trade to COMESA and what other factors facilitate exports by Kenya?

The policy objective to increase regional trade require choosing between national and regional policy priorities. The policy choice between reforms or domestic infrastructure depends on which is domestically perceived as trade inhibiting. High priority to domestic infrastructure investment, without complementary policy regulatory reforms is unlikely to produce optimal trade outcomes. This more so when regulatory induced nontariff barriers pose greater cross-border barriers to regional trade.

Therefore, understating whether investment in economic infrastructure is effective in increasing regional trade relative to better trade policy and regulations or vice versa should contribute to better choices. This study seeks to build on previous empirical literature on trade facilitation by focusing on the inter-regional trade by Kenya. The study goes beyond the effect of the aid for trade for trade policy and infrastructure and introduces economic 
infrastructure and regulatory quality variables to determine the relationship between trade flows and the control factors when aid for trade is present.

\subsection{Empirical Literature}

In countries with good institutions and capacity, like better trade regulations and policies, customs procedures and documentations, AfT is complementary to capital accumulation; on the contrary, countries with poor institutional structures, AfT is not easily transferable to better trade outcomes. Addressing the empirical gap, Ferro et al, (2011) classified countries into different income levels. The authors evaluate the impact of AfT using an input-output tables in five service sectors for 48 countries. The conclusion is that aid channelled into transport and energy sectors is effective in increasing exports, but less so to the business sector. The results from developing countries underscore one of the challenges to trade; that poor infrastructure is a barrier both for domestic and international trade.

Portugal-Perez and Wilson (2010) examine the effect of AfT on 101 developed and developing countries within an extended gravity model augmented with trade barrier information from World Doing Business reports and Transparency International sources. They use different trade facilitation indicators like infrastructure, technology and border efficiency that affect trade in mining, manufacturing and services sectors. The authors use a two-stage Heckman selection model for estimation. The authors find that that infrastructure has larger effect in mining industry compared to textiles and manufactures sectors. Aid is given to ICT, has a negative effect in the fuels sector and significantly related to ores and metals industries.

Busse et al, (2011) define AfT by aggregating funds for trade policy and regulations for both developing countries including 33 LDCs and non-LDCs top 20 aid recipients. The authors estimate the effect of AfT on the cost of trading using fixed-effects in a panel data-set. The results show that AfT is significant in reducing the costs of trading, although the effect varies with the aid category. When channelled into trade policy and regulations, AfT is effective relative a general aid for trade. But the effectiveness of AfT in reducing transaction time is less significant, while aid directed towards policy and regulations is significant, but has marginal effect in reducing the period of transactions.

Helble et al, (2009) use a gravity model with panel fixed-effects for 172 developed and developing countries on OECD-CRS data. The authors use trade policy, trade development, and infrastructure as the main variables. The overall result is that increasing AfT facilitation by one per cent generate US dollar 415 million increase in global trade.

Ivanic et al, (2006) classify countries into income and geographical zones. The sample include developed countries; East Asia and Pacific; Europe and Central Asia, Latin America and Caribean; Middle East and North Africa; and Sub-Saharan Africa. The authors used a CGE model by first estimating the effects of trade promotion on world transaction costs, AfT was determined to be welfare enhancing.

Wilson et al, (2004) use harbour infrastructure, customs, regulations, and technology facilities to investigate the benefit of AfT. They use data in the manufacturing industry from 75 countries for the period 2000 to 2001 in a gravity model. The results is that aid given to the four variables, increase both exports and imports. The results showed that improvements in countries rated below-average to half of global average increased export and imports by US dollar 107 billion and US dollar 33 billion respectively and developing countries importers benefited the most from better customs administration and port efficiency.

APEC (2002) determine whether trade facilitation promote intra-APEC transactions. The study examines customs procedures in the region, and determine that improving customs procedures by 10 per cent, increase import trade by 0.5 per cent within APEC. Kim et al, (2004) find similar results that reducing customs clearance time by half generate 1.7-3.4 per cent imports for industrialised APEC economies, 2.0-4.5 per cent in newly industrialised, and 7.7-13.5 per cent in industrialising APEC countries. The results are consistent with those of Wilson et al. (2003) who examine the impact of addressing port efficiencies. They determine that improved port performance generated about 9.7 percent gain (US dollar 117 billion) to the economies, while improving customs procedures resulted to 1.8 per cent (US dollar 22 billion) gain.

\subsection{Empirical model and definition of variables}

Gravity model is popular in empirical studies on international trade due to its empirical robustness (Novy, 2011). The model allows for augmenting with key variables to answer specific research questions. The traditional control variables in gravity models are; economic size, population, trade intensity, infrastructure, language, REC, colonial ties, borders, trade cost variables and distance. We extend the work of Hoekman and Nicita (2008) and Anderson and van Wincoop (2003) by explicitly examining how AfT for policy reforms and economic infrastructure relates with export trade. The foundational structure of gravity model derived from the Dornbursh Fisher Samuelsson (DFS) theoretical framework (Dornbusch et, al 1977) is: 


$$
X_{i j}=\frac{Y_{i} Y_{j}}{Y_{w}}\left[T_{i j} / P_{i} P_{j}\right]^{1-\sigma}
$$

Where: $\mathrm{Y}_{\mathrm{i}} \mathrm{Y}_{\mathrm{j}}$ and $\mathrm{Y}_{\mathrm{w}}$ define the economic size of countries $i, j$ and the world, in that order; Tij is the trade costs variable and other transaction barriers; $\mathrm{Pi}$ and $\mathrm{Pj}$ give equilibrium prices; and $\sigma$ is the constant elasticity of substitution (CES) between all goods in the utility function as derived from the DFS model, and $T_{i j}$ gives the obstacle due to geography.

This paper use trade policies/regulations and the density of infrastructure in Kenya as the trade facilitation barriers, identified in the gravity model as $P i$ and $P j$ shown in Equation 1 . The baseline model for estimation in a gravity model is given by equation (2).

$$
X_{i j}=\beta_{o} Y_{i}^{\beta_{1}} Y_{j}^{\beta_{2}} N_{i}^{\beta_{3}} N_{j}^{\beta_{4}} D_{i j}^{\beta_{5}} A_{i j}^{\beta_{6}}
$$

Where the variable;

Xij- gives the trade in volume or value between the two countries $i$ and $j$;

$\mathrm{Y}$-is the income levels given either by GDPs or GDP per capita of the two trading countries;

$\mathrm{N}$-is the population size of the trading countries;

D-defines either geographical or commercial distance between them; and

A is a set of dummies of other factors that influence trade included in the traditional gravity model.

To achieve the research objective whether AfT is effective in facilitating trade flow in Kenya. This study augment equation (2) with the variables that capture AfT facilitation om policy and regulation and infrastructure density. AfT is defined using two categories $u$ of infrastructure variable, and policy and regulations variable which are included in the model for estimation purpose.

The study estimate three linear regressions models; the first estimation include all the AfT variables; the second estimation, include only aid for policy and regulations variable, while the third estimation introduce aid for economic infrastructure. The estimation is done in natural logarithm for the continuous variables to allow for the interpretation of the coefficients as elasticities. The estimation equation is shown in equation 3 .

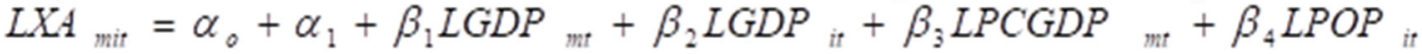

$$
\begin{aligned}
& +\beta_{5} \text { PPOP }_{m t}+\beta_{6} L I N E_{i t}+\beta_{7} L I N F_{i t}+\beta_{8} L I N F_{m t}+\beta_{9} L A f T_{\text {it }}
\end{aligned}
$$

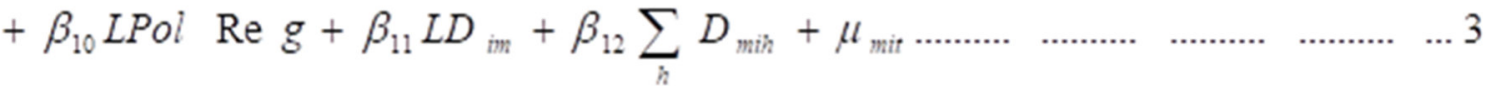

Where:

$i$ and $m=$ exporting and importing countries in EAC;

Trade Flow (Export) $=X A_{\text {mit }}^{k}$ is the variable for trade flows from country ${ }^{(i)}$ to country; and $(m)$ in the broad product category $(k)$ in period ${ }^{(t)}$

Gross Domestic Product $(Y)=$ the gross domestic product (GDP) of countries $i$ and $m$ respectively. GDP is taken to be positively related to exports.

Gross Domestic Product per Capita $(P C G D P)=$ the GDP per capita of countries i and m respectively. GDP per capita is negatively related to exports due to greater self-sufficiency.

Infrastructure $\left(\mathrm{INF}_{\mathrm{imt}}\right)=$ the variable defines the infrastructure density existing in the exporting, and importing country at time $t$. It hypothesises that infrastructure has a positive effect on intra-EAC trade.

Aid for Trade $\left(A f T_{i t}\right)=$ is the variable that defines AfT facilitation which is categorised into three: Aid for Economic Infrastructure, Policy and Regulations. The effect of AfT for economic infrastructure is expected to be positive.

Policy and Regulation $($ PoReg) = the variable of policy and regulatory environment in the exporting country. It is expected that better policies and regulations have positive effects on exports.

Bilateral Distance $($ Dim $)=$ gives the resistance between countries $\mathrm{i}$ and $\mathrm{j}$. This follows the traditional gravity model where it represents the commercial distance between capitals as a measure of the trade resistance between countries. Distance between trading centres is expected to negatively affect trade flows.

Dummy Variables $=\sum \beta_{h} D_{\text {mih }}$ is used to express the different dummy variables expected to influence trading within a gravity model. The study uses as dummies, the main languages (French or English) spoken in the region, membership to the EAC Customs Union and sharing of borders (the dummy takes value of 1 if the condition is true or 0 otherwise) as dummies. The membership to a common RTA, sharing of borders 
and speaking common language is hypothesised to positively affect trade flows. $\mu_{i m t}=v_{i m t}+\varepsilon_{i m}$ and

$v_{i m t}$ is unobserved random or fixed bilateral effect, while ${ }^{\varepsilon_{i m}}$ is the remaining effect.

\section{Data, and data sources and Analysis}

The study uses annual secondary data for the period 2003 to 2012 in the empirical analysis in section 2.7. This data is sourced from COMESA trade data portal that has the value of total imports and exports at an aggregated level. The timeframe of study fits with the period pre and post "Enhanced" AfT as an instrument for Overseas Development Assistance (ODA). This captures the changes in the flow of AfT to Kenya as aggregated from all DAC members.

World Development Indicators from the World Bank data capture different indicators like the internet access per 100 persons, gross domestic product per capita, gross domestic product and population. The data on internet access, GDP per capita and population for ESA countries was sourced from the World Bank's database while fixed telephone subscriptions is from the World Telecommunication Organisation. Additionally, the policy and regulatory indicators are usually published by the World Bank in their Worldwide Governance Index (WGI) data. From the Creditor Reporting System (CRS) provide data on the two categories of AfT disbursed for trade policy and regulation reforms, and for economic infrastructure. CRS classifies aid as per the WTO definition of Aid for Trade as reported by DAC members, hence it is more realistic to specific policy areas. The economic infrastructure aid includes funds used for improving energy generation and supply, transport and storage, and communication. The data is obtained from the World Bank as reported by the OECD CRS aid database. Data on distance (in kilometres) between the economic capitals of the trading partners were obtained from CEPII website at (www.cepii.fr ).

\subsection{Data Analysis}

For estimation the natural log form of the real export values in current US dollars; real GDP per capita; population; fixed telephone subscriptions; internet per 1,000 persons; regulatory quality and bilateral distance are used. In the tradition of gravity model estimations, dummy variables in the estimation include sharing common borders, membership to an RTA and a common language. Table 1 presents the descriptive statistics. The estimation results are in the next section.

The mean value of trade flows from Kenya to the COMESA region is varied from the standard deviation. Whereas aid for policy and regulations seems not to change much, aid for economic infrastructure is widely dispersed. Similarly, regulatory quality and fixed telephone line both in Kenya and importer countries are varied. Though GDP per capita of the importing countries are widely dispersed, Kenya's GDP per capita seems not to have been varying over the years. A pre-estimation test for possible correlation among the variables is done, giving VIF of 10.93 which is within the range for low correlation. The panel is balanced, thus use panel estimation methods. Therefore, either a random or fixed effects is estimated. Hausman specification test reject the fixed effects estimation in favour of random effects method. Table 2.2 presents the estimation results based on the random effects model. There are four columns showing the variables used, when different aid for trade categories are included. The second column showing when all the AfT variables are included in the regression, second column when only aid for policy and regulations and third when only aid for economic infrastructure are introduced in the model. The specifications of gravity model contain possible causality between income and trade (Cyrus, 2002). Some argue that increasing income causes high trade; this is contrary to the position that trade could be causing income growth (ibid). We account for possible reverse causality in the model by estimating Hausman-Taylor model that allows for the inclusion of time invariant dummy variables. The results are shown in Table 2

\subsection{Analysis of the Effect of Aid for Trade}

The results (Table 2.2) indicate that AfT jointly given is significant and positive effects on export trade in Kenya. Increasing aid for economic infrastructure by 1 per cent, could increase exports by 1.47 per cent. The intuition is that improving infrastructure has productivity boosting effect, while increasing aid for policy and regulations has a marginal increases in exports. The economic magnitude for policy effect is smaller due to generally low funds being directed at policy reforms and possible differences between the trade reforms and policy implementation. The findings is supported by Lemi (2014) who estimate the role of all the AfT categories and trade between donors and recipient countries in SSA. The coefficient for aid for policy and regulations had the expected sign, although turns e non-significant when singularly included without aid for infrastructure in the estimation. This demonstrate the complementarities between aid for economic infrastructure and aid for policy and regulations. The regulatory quality variable as a measure for policy and regulation reforms was significant and had the expected positive signs in all the estimations. Thus, enhancing the quality of regulation by 1 per cent boosts exports by 6.8 .8 when all the categories of aid are given, and by 1.94 per cent when only aid for policy and regulations is disbursed, and increase 
trade by 7.2 per cent when combined with aid for economic infrastructure.

The were mixed results for infrastructure indicators (fixed telephone subscriptions and internet). Increasing the stock of infrastructure (telephone and internet per 1000 persons in Kenya) by 1 per cent would increase trade by 0.9 per cent and 0.29 per cent respectively When used in the estimation with the two aid categories, the coefficient was positive, however this turn negative when only policy and regulatory aid or economic infrastructure funds are used in the estimations. Export is reduced by 0.62 per cent when only policy and regulatory funds is used and negatively affected by 0.95 per cent when only infrastructure money is given. The contradiction is explained by the findings of Lemi (2014), who determine that road network and mobile telephone as indicators for infrastructure turned negative in some of the estimations. The explanation could be that that receiving only one kind of aid either for policy or infrastructure does not generate the necessary threshold for regional exports. Thus, Kenya exporters find it easier to export to other regions, probably traditional export destinations, with established communication infrastructure rather than within the region with similar or lower infrastructure status.

The variables used to control for economic size (population), in terms of production and market size had the expected positive signs and significantly affect trade in all the model specifications. This could mean that Kenya's trade depends on the production size and those of her trading partners, with a 1 per cent growth in Kenya's economy increase exports by 5.56 per cent when infrastructure is improved, while increasing partner economy's trade by 0.93 per cent. Economic size of Kenya is consistently significant in all the estimations increasing trade by 13.1 percent with only aid for policy and 5.61 per cent when infrastructure aid is given. The intuition is that there is a "home market" effect as the basis of more trade by Kenya. This is similar to the findings of Mahona and Mjema (2014) who determine how population of Tanzania and Kenya affect their bilateral trade. GDP per capita as a measure of the purchasing power and productivity for both the exporting (Kenya) and importing countries (COMESA countries) is positive and significant in relation to Kenya's exports. However, Kenya's GDP per capita is found to negatively relate with her exports. One per cent increase in GDP per capita in importing country increased trade by 0.52 per cent while GDP per capita for Kenya reduced trade by 1.92 per cent. The implication is that Kenya's export trade is driven more by her GDP rather than per capita and productivity.

The geographical distance coefficient was used as a measure for the resistance (measuring time to export) between the trading pairs. This had the expected negative sign and significant on trade flows in all the estimations. Increasing distance by one per cent reduces trade by about 3 per cent, is similar to the findings of Mahona and Mjema (2014).This imply Kenya is trading more with countries in closer proximity rather than distant ones within COMESA.

There is possible endogeneity between trade flows and GDP per capita, AfT and regulatory reforms in the presence of time invariant factors in the model (Lemi, 2014), Thus the need to estimate Hausman-Taylor model, the results are shown in Table 2.2 below. Aid for economic infrastructure is consistently significant in determining exports in all the estimations, even when disbursed without including policy variable in the estimation. Increasing aid for economic infrastructure by 1 per cent increases exports by 1.47 per cent. Surprisingly, when aid for policy is introduced it turned negative although has insignificant effect on trade. Increasing aid for policy would reduce exports by 0.007 per cent. This could be explained by introducing stringent regulations, e.g. conformity standards without complementary improvement in infrastructure impose a compliance burden on exports thus

The regulatory quality was positive on trade flows in all the estimations whereby improving regulatory quality by 1 per cent positively increase trade by 6.77 per cent when all aid is given; by 3.79 per cent when only aid for policy and regulations is given; and by 5.29 per cent when aid for economic infrastructure is given. Fixed telephone and internet access in Kenya turned out to negatively affect Kenya's exports, but not in a significant manner except when all the categories of aid is disbursed. Internet per 1000 persons reduces trade by 0.287 per cent. This could highlight that when possible endogeneity in the model is accounted for, Kenya's exports shift away from the region, such that the country trade with alternative markets, possibly, donors. GDP per capita of the importer had the expected signs and was significant when all the two categories of aid are disbursed. Thus, importer per capita increase by 1 percent exports increases trade by 0.63 per cent but was 0.77 per cent when only aid for policy and regulation is given. The significance of the constant term when only aid for policy and regulations was used in the estimation highlights the important role of infrastructure money in trade.

\section{Conclusion}

The study examined South-South trade which has received limited attention in empirical literature. Following in the line of previous works on AfT facilitation the study sought to determine the effect of AfT facilitation, specifically aid disbursed for policy and regulation reforms and aid for economic infrastructure to Kenya. To add value, rather than examine trade relations between the donors and recipient countries, the study explored export trade by aid recipient countries that are between Kenya to COMESA member countries.

To achieve the purpose of this study the empirical estimation included policy variables and infrastructure indicators to determine how these two variables relate with export trade to the region. The main reason is that addressing infrastructure without complementary policy reforms, has been cited as less optimal in effecting trade 
outcomes.

The study included disbursed funds meant for policy and infrastructure in the first estimation, while accounting for other control variables used in gravity estimations. The results indicate that aid for economic infrastructure was a key determinant for export trade by Kenya. Increasing funds to improve road network, energy supply, port facilities, transport and communication would thus enhance trade by Kenya. Equally, better regulatory environment facilitates for trade in Kenya. More specifically, availing both kinds of aid for policy reforms and infrastructure is desirable. This provides a policy rationale for increasing e trade through AfT.

In addition, the findings highlighted that increased connectivity though internet and fixed telephone could be driving Kenya's exports away from the region to other destinations. The intuition is that with better communications exporters from the country find it easy to link with other traders outside the COMESA region. Although this may appear to be diverting trade, the finding is revealing since improving communication access allows the country to diversify her trade, by retaining other export destinations while using aid to expand into the region. Additionally, membership to COMESA beyond the EAC customs union appears to have reduced the possible effect tariff liberalization under CET as a major determinant of trade flows. Consequently, the policy insight from this outcome is that to expand South-South trade requires a combination of increasing AfT while enhancing global connectivity though faster communication systems.

In conclusion, the paper identified the supply-side factors that influence export trade from Kenya into the Eastern Africa region by estimating three models, including all the two categories of AfT; policy and regulatory environment, and an economic infrastructure density. The study supports the argument that AfT is trade enhancing and not just between donors and recipient countries but trade among AfT recipient countries. Further, the study highlights that giving aid while improving the communications systems can serve as an avenue to diversify export trade into different markets both within and without the region. Addressing the policy and regulatory challenges is important too. This is necessary in reducing within the border factors such as number of trade documentations required, customs procedures, weigh bridge inspections, and standard conformity assessment, to facilitate easy flow of goods within the region.

The policy recommendations therefore are: support development of new infrastructure as well maintain the existing ones including the ports, improve access roads and border facilities; policy reforms around harmonizing standards and reducing bureaucratic procedures and joint regional investments on trade facilitation; to monitor identify, and eliminate non-tariff barriers along the trade corridors, to encourage Good Manufacturing Practices (GMP) by exporters and to institutionalize advocacy transparency in trade processes in the region.

\section{References}

Adam, C. and Bavan S. D. (2006). Aid and Supply Side: Public Investment, Export Performance and Dutch Disease in Low Income Countries. World Bank Economic Review 20(2):261-90.

Anderson, J. and van Wincoop E. (2003). Gravity with gravitas. A Solution to the Border Puzzle. American Economic Review, 93, 170-192.

Collier, P., \& Gunning, J. (1997) 'Explaining African Economic Performance' WPS/97-2.2. Oxford: Centre for African Economies:

Chowdhury, A. \& Erdenebileg S. (2006). Geography Against Development: A Case for Landlocked Developing Countries. United Nations Office of the High Representative for the Least Developed Countries, Landlocked Developing Countries and Small Island Developing States (UN-OHRLLS).

Dornbusch, R. Fischer, S. Samuelson P. A.(1977). Comparative Advantage, Trade, and Payments in a Ricardian Model with a Continuum of Goods. The American Economic Review, Vol. 67, No. 5, (Dec., 1977), pp. 823839.

Ferro, E., Portugal-Perez, A. and Wilson, J.S. (2011) 'Aid to the Services Sector. Does It Affect Manufacturing Exports?' Policy Research Working Paper 5728. Washington, DC: World Bank.

Helble, M., Catherine M. and John W. (2009). Aid for Trade Facilitation. World Bank Policy Research Paper 5064. Washington DC.

Ivanic, M., Mann, L. and Wilson S. (2006). 'Aid-for-Trade Facilitation.' Global Welfare Gains and Developing Countries'.

Kirkpatrick, Colin and Watanabe, Matsuo. (2005). Regional trade in Sub-Saharan Africa: An analysis of East African Trade Cooperation, 1970-2001. The Manchester School Vol .73 No.2 1463-6786.

Lemi A. (2014). Aid for Trade And the Scramble for Africa's Trade: West vs. East. University of Massachusetts USA. Mimeo.

Limao, N., and Venables J. (2001). Infrastructure, Geographical Disadvantage, Transport Costs, and Trade, The World Bank Economic Review, 15, 451-479.

Mahona B. and Mjema D. (2014). Determinants of Tanzania and Kenya Trade in the East African Community: A Gravity Model Approach. Journal of Economics and Sustainable Development. Vol.5, No.4.

Novy, D. (2011). Gravity Redux: Measuring International Trade Costs with Panel Data. Department of Economics, 
University of Warwick.

ODI (Overseas Development Institute) (2013). Focusing on What Matters in Aid for Trade. Increasing Effectiveness and Delivering Results.

OECD/WTO (Organisation for Economic Co-operation and Development) and WTO (World Trade Organization) (2011) Aid-for-Trade at a Glance 2011: Showing Results. Paris and Geneva: OECD/WTO.

Pearson, M. (2011). Trade Facilitation in Tripartite COMESA-SADC-EAC Free Trade Area. TRALAC. Working Paper .SIIWPII/2011.

Portugal-Perez A. \& Wilson J.(2009). Why trade facilitation matters to Africa. World Trade Review. Vol, 8:3, 379-416.

Suwa-Eisenmann, A. \& Verdier T. (2007). Aid and trade. Oxford Review of Economic Policy, 23(3),481-507.

Vijil M.(2012). Aid for Trade Effectiveness: Complementarities with Economic Integration. Paper prepared for the Workshop. "Aid for Trade: What Have we Learnt? Which way Ahead?" International Conference Centre, Geneva. (mimeo).

Table 1. Descriptive Statistics of the Variables

\begin{tabular}{l|l|l|l|l|l}
\hline Variable & Obs & Mean & Std. Dev. & Min & Max \\
\hline Export value from Kenya & 190 & 14.392 & 2.374 & 6.845 & 18.897 \\
\hline AfT for policy and regulations & 190 & .161 & 1.088 & 1.863 & 2.169 \\
\hline AfT for economic infrastructure & 190 & 5.179 & .587 & 4.375 & 6.315 \\
\hline Regulatory quality in Kenya & 190 & 3.849 & .050 & 3.7294 & 3.917 \\
\hline GDP per capita in Kenya & 190 & 2.108 & .0781 & 1.977 & 2.227 \\
\hline GDP per capita in importer country & 190 & 1.609 & 1.437 & 2.058 & 4.789 \\
\hline Population in Kenya & 190 & 17.460 & .0773 & 17.339 & 17.581 \\
\hline Population in importer country & 190 & 15.882 & 1.816 & 11.321 & 18.334 \\
\hline Fixed telephone in Kenya & 190 & 12.814 & .333 & 12.435 & 13.406 \\
\hline Fixed telephone in importer country & 190 & 11.702 & 1.683 & 8.161 & 16.288 \\
\hline Internet per 1,000 people in Kenya & 190 & 5.213 & 3.677 & 1.164 & 12.033 \\
\hline Internet per 1,000 people in importer country & 180 & 3.424 & 3.866 & 0 & 14.836 \\
\hline
\end{tabular}

Table 2. Random Effects Model Results

$\begin{array}{llll}\text { Variables } & (1) & (2) & (3) \\ \text { All aid for trade } & \begin{array}{l}\text { Aid for policy and } \\ \text { regulation }\end{array} & \begin{array}{l}\text { Aid for economic } \\ \text { infrastructure }\end{array}\end{array}$

\begin{tabular}{|c|c|c|c|}
\hline Aid for Policy Regulations & $\begin{array}{l}0.1044 * * \\
(0.0509)\end{array}$ & $\begin{array}{l}0.0865 \\
(0.0535)\end{array}$ & \\
\hline Aid for Economic Infrastructure & $\begin{array}{l}1.4773 * * * \\
(0.2062)\end{array}$ & & $\begin{array}{l}1.4473^{* * *} \\
(0.2138)\end{array}$ \\
\hline Regulatory Quality & $\begin{array}{l}6.8294 * * * \\
(1.1645)\end{array}$ & $\begin{array}{l}1.9411 * * \\
(0.9038)\end{array}$ & $\begin{array}{l}7.2015^{* * * *} \\
(1.1531)\end{array}$ \\
\hline GDP per capita of Kenya & $\begin{array}{l}-1.9157 \\
(1.7007)\end{array}$ & $\begin{array}{l}-0.9006 \\
(1.7872)\end{array}$ & $\begin{array}{l}-1.1207 \\
(1.4166)\end{array}$ \\
\hline GDP per capita of Importer country & $\begin{array}{l}0.5220 * * \\
(0.2064)\end{array}$ & $\begin{array}{l}0.5249 * * \\
(0.2094)\end{array}$ & $\begin{array}{l}0.5269 * * \\
(0.2118)\end{array}$ \\
\hline Population of Kenya & $\begin{array}{l}5.5635 * * \\
(2.5682)\end{array}$ & $\begin{array}{l}13.1048 * * * \\
(2.0814)\end{array}$ & $\begin{array}{l}5.6130 * * \\
(2.5638)\end{array}$ \\
\hline Population of importer country & $\begin{array}{l}0.9269 * * * \\
(0.1416)\end{array}$ & $\begin{array}{l}0.9314 * * * \\
(0.1477)\end{array}$ & $\begin{array}{l}0.9305 * * * \\
(0.1437)\end{array}$ \\
\hline Tel per 1,000 persons Kenya & $\begin{array}{l}0.9085 * * * \\
(0.2859)\end{array}$ & $\begin{array}{l}-0.6224 * * \\
(0.3131)\end{array}$ & $\begin{array}{l}-0.9505 * * * \\
(0.3006)\end{array}$ \\
\hline Tel per 1,000 persons Importer & $\begin{array}{l}0.0178 \\
(0.1381)\end{array}$ & $\begin{array}{l}0.0070 \\
(0.1346)\end{array}$ & $\begin{array}{l}0.0113 \\
(0.1354)\end{array}$ \\
\hline Internet per 1,000 persons Kenya & $\begin{array}{l}0.2872 * * * \\
(0.0596)\end{array}$ & $\begin{array}{l}-0.2232 * * * \\
(0.0645)\end{array}$ & $\begin{array}{l}-0.2459 * * * \\
(0.0501)\end{array}$ \\
\hline Internet per 1,000 persons importer & $\begin{array}{l}0.0574 \\
(0.0377)\end{array}$ & $\begin{array}{l}0.0566 \\
(0.0369)\end{array}$ & $\begin{array}{l}0.0557 \\
(0.0374)\end{array}$ \\
\hline Sharing of borders & $\begin{array}{l}-0.0503 \\
(0.6426)\end{array}$ & $\begin{array}{l}-0.0306 \\
(0.6339)\end{array}$ & $\begin{array}{l}-0.0494 \\
(0.6388)\end{array}$ \\
\hline
\end{tabular}




\begin{tabular}{|c|c|c|c|}
\hline Variables & All aid for trade & $\begin{array}{l}(2) \\
\text { Aid for policy and } \\
\text { regulation }\end{array}$ & $\begin{array}{l}\text { (3) } \\
\text { Aid for economic } \\
\text { infrastructure }\end{array}$ \\
\hline Geo Geographical distance & $\begin{array}{l}-2.7774 * * * \\
(0.8038)\end{array}$ & $\begin{array}{l}-2.7448 * * * \\
(0.8043)\end{array}$ & $\begin{array}{l}-2.7562^{* * *} \\
(0.8089)\end{array}$ \\
\hline Co Common language & $\begin{array}{l}-1.1463 \\
(0.7219)\end{array}$ & $\begin{array}{l}-1.1504 \\
(0.7266)\end{array}$ & $\begin{array}{l}-1.1425 \\
(0.7207)\end{array}$ \\
\hline Member to RTA(EAC-CU) & $\begin{array}{l}-0.0735 \\
(0.2356)\end{array}$ & $\begin{array}{l}-0.0441 \\
(0.2407)\end{array}$ & $\begin{array}{l}-0.0495 \\
(0.2283)\end{array}$ \\
\hline Co Constant & $\begin{array}{l}94.3275 * * \\
(40.3978)\end{array}$ & $\begin{array}{l}205.8608 * * * \\
(34.6490)\end{array}$ & $\begin{array}{l}-97.9532 * * \\
(40.2873)\end{array}$ \\
\hline Ob $\quad$ Observations & 180 & 180 & 180 \\
\hline $\mathrm{N} \quad$ Number of country & 19 & 19 & 19 \\
\hline Overall R-sq & 0.702 & 0.696 & 0.701 \\
\hline $\mathrm{F}$ tes $\mathrm{F}$ test & 0.789 & 0.779 & 0.788 \\
\hline
\end{tabular}

Robust standard errors in parentheses $* * * \mathrm{p}<0.01, * * \mathrm{p}<0.05, * \mathrm{p}<0.1$

Table 3. Hausman-Taylor Estimation Results

\begin{tabular}{|c|c|c|c|}
\hline Variables & $\begin{array}{l}\text { (1) } \\
\text { All aid for } \\
\text { trade }\end{array}$ & $\begin{array}{l}(2) \\
\text { Aid for policy and } \\
\text { regulation }\end{array}$ & $\begin{array}{l}\text { (3) } \\
\text { Aid for economic } \\
\text { infrastructure }\end{array}$ \\
\hline Aid for policy regulations & $\begin{array}{l}0.1030 \\
(0.0920)\end{array}$ & $\begin{array}{l}-0.0070 \\
(0.0834)\end{array}$ & \\
\hline Aid for economic infrastructure & $\begin{array}{l}1.4749 * * * \\
(0.4472)\end{array}$ & & $\begin{array}{l}0.9067 * * \\
(0.4364)\end{array}$ \\
\hline Tel per 1,000 persons Kenya & $\begin{array}{l}-0.9134 * * * \\
(0.2676)\end{array}$ & $\begin{array}{l}-0.3808^{*} \\
(0.2251)\end{array}$ & \\
\hline Tel per 1,000 persons importer & $\begin{array}{l}0.0492 \\
(0.1900)\end{array}$ & $\begin{array}{l}0.0130 \\
(0.1944)\end{array}$ & \\
\hline Internet per 1,000 persons Kenya & $\begin{array}{l}-0.2872 * * * \\
(0.0937)\end{array}$ & & $\begin{array}{l}-0.0680 \\
(0.0732)\end{array}$ \\
\hline $\begin{array}{l}\text { Internet per } 1,000 \text { persons importer } \\
\text { country }\end{array}$ & $\begin{array}{l}0.0501 \\
(0.0394)\end{array}$ & & $\begin{array}{l}0.0515 \\
(0.0393)\end{array}$ \\
\hline GDP per capita of importer & $\begin{array}{l}0.6297^{*} \\
(0.3509)\end{array}$ & $\begin{array}{l}0.7683 * * \\
(0.3687)\end{array}$ & $\begin{array}{l}0.5133 \\
(0.3384)\end{array}$ \\
\hline Population of Importer country & $\begin{array}{l}0.9170 * \\
(0.4790)\end{array}$ & $\begin{array}{l}0.3949 \\
(0.8984)\end{array}$ & $\begin{array}{l}0.9073 * * \\
(0.3921)\end{array}$ \\
\hline Membership to RTA(EAC-CU) & $\begin{array}{l}-0.0460 \\
(0.3740)\end{array}$ & $\begin{array}{l}0.0939 \\
(0.3745)\end{array}$ & $\begin{array}{l}0.0127 \\
(0.3851)\end{array}$ \\
\hline Population of country in Kenya & 5.6356 & $6.2279 * * *$ & 0.8042 \\
\hline Regulatory quality Kenya & $\begin{array}{l}(4.3929) \\
6.7672 * * * \\
(2.2240)\end{array}$ & $\begin{array}{l}(1.8262) \\
3.7949 * * * \\
(1.3544)\end{array}$ & $\begin{array}{l}(4.2891) \\
5.2932 * * \\
(2.2151)\end{array}$ \\
\hline GDP per capita of Kenya & $\begin{array}{l}-1.9483 \\
(1.3841)\end{array}$ & $\begin{array}{l}0.1959 \\
(1.2190)\end{array}$ & $\begin{array}{l}-1.2546 \\
(1.2265)\end{array}$ \\
\hline Sharing of borders & $\begin{array}{l}-0.0595 \\
(2.2183)\end{array}$ & $\begin{array}{l}1.2363 \\
(4.5134)\end{array}$ & $\begin{array}{l}-0.0004 \\
(1.7842)\end{array}$ \\
\hline Geographical distance & $\begin{array}{l}-2.9002 * \\
(1.5072)\end{array}$ & $\begin{array}{l}-2.6070 \\
(2.9925)\end{array}$ & $\begin{array}{l}-2.6805^{* *} \\
(1.1935)\end{array}$ \\
\hline Common language & $\begin{array}{l}-1.2672 \\
(1.5717)\end{array}$ & $\begin{array}{l}-1.3629 \\
(3.2138)\end{array}$ & $\begin{array}{l}-1.1230 \\
(1.2729)\end{array}$ \\
\hline Constant & $\begin{array}{l}-94.6018 \\
(69.9167)\end{array}$ & $\begin{array}{l}-92.4554 * * \\
(38.8552)\end{array}$ & $\begin{array}{l}-16.7253 \\
(67.0863)\end{array}$ \\
\hline Observations & 180 & 190 & 180 \\
\hline Number of countries & 19 & 19 & 19 \\
\hline
\end{tabular}

